\title{
Growth Dynamics following Planting of Cultivars of Juniperus chinensis
}

\author{
Edward F. Gilman and Michael E. Kane \\ Environmental Horticulture Department, Institute of Food and Agricultural Sciences, University of \\ Florida, Gainesville, FL 32611
}

\begin{abstract}
Additional index words. transplanting, plant establishment, crown form, root growth, root area, shoot : root ratio, landscape
\end{abstract}

\begin{abstract}
Shoot and root growth were measured on Chinese juniper ( Juniperus chinensis L. 'Torulosa', 'Sylvestris', 'Pfitzeriana', and 'Hetzii') 1, 2, and 3 years after planting from 11-liter black plastic containers. Mean diameter of the root system expanded quadratically, whereas mean branch spread increased linearly. Three years after planting, root spread was 2.75 times branch spread, and roots covered an area 5.5 times that covered by the branches. Percentage of total root length located within the dripline of the plants remained fairly constant for each cultivar during the 3 years following planting. Root length density increased over time but decreased with distance from the trunk. During the first 2 years after planting, shoot mass increased faster than root mass. In the 3rd year, the root system increased in mass at a faster rate than the shoots. Root length was correlated with root weight. Root spread and root area were correlated with trunk cross-sectional area, branch spread, and crown area.
\end{abstract}

Root system morphology can influence survival, stability, growth, and transplantability of trees (Van Eerden and Kinghorn, 1978). The root system that develops on seeded-in-place trees is a function of seedling genotype and soil characteristics, such as texture, compaction, fertility, depth to the water table, soil moisture content, and soil insect activity (Gilman, 1990a). Root morphology on planted trees is also influenced by nursery production practices, tree age at planting, planting method, and postplanting cultural practices (Preisig et al., 1979).

Root growth extends beyond the dripline in forest trees in a closed-canopy stand (Stout, 1956) or in a forest clearing (Hodgkins and Nichols, 1977). On nursery-grown trees, root spread : branch spread ratio was species-dependent, ranging from 1.7 to 3.7 times the dripline for green ash (Fraixinus pennsylvanica Marsh.) and southern magnolia (Magnolia grandiflora L.), respectively. Roots on orchard-grown pear (Pyrus spp. L.) and apple (Malus spp. Mill.) also extended two to three times the distance from the trunk to the branch dripline (Rogers, 1933; Rogers and Vyvyan, 1934). Frequently, roots on established trees extend to encompass a roughly circular area four to seven times the area beneath the branches (Stout, 1956), with a diameter of one, two, or more times the height of the tree (Bushey, 1937) or shrub (Gilman, 1989). Roots growing farthest from the trunk are consistently found near the soil surface. The deepest roots are found closer to the trunk (Bushey, 1937).

Sixty percent of 8-year-old Colorado blue spruce (Picea pungens Engelm.) root surface area and dry weight was outside of the dripline (Watson and Syndor, 1987). Five-year-old honey locust (Gleditsia triacanthos L.), green ash, and poplar (Populus $\times$ generosa A. Henry) had 59\%, 54\%, and $77 \%$, respectively, of total root length outside of the dripline (Gilman, 1988a). Percentage of total root length within the dripline was correlated with the plant height : crown spread ratio on Chinese juniper 1 year after planting (Gilman, 1989).

Previous root excavations have been conducted at one time only or over time for only a short period (Blessing and Dana, 1988). Growth ring analysis showed that lateral roots on red maple (Acer rubrum L.) increased in length at 45 to $135 \mathrm{~cm} \cdot \mathrm{year}^{-1}$

Received for publication 18 June 1990. Florida Agricultural Experiment Station Journal Series no. R-01002. The cost of publishing this paper was defrayed in part by the payment of page charges. Under postal regulations, this paper therefore must be hereby marked advertisement solely to indicate this fact.
(Wilson, 1964). Elongation rate for red pine (Pinus resinosa Ah.) was 46 and $68 \mathrm{~cm} \cdot y e a r^{-1}$ on two sites (Fayle, 1974). However, this analysis is often unreliable because of discontinuous growth rings (Wilson, 1964).

Considering the wealth of information on landscape horticulture, it is surprising how little is known about root growth. For instance, it is unknown how quickly roots grow from the root ball. Is the distribution of roots closely related to the shape and size of the canopy? How does shoot : root ratio at planting compare with that several years after planting? How long does it take before a plant is considered established? Therefore, the objective of this study was to describe, by root excavations, the dynamics of root, shoot, and trunk growth of four cultivars of Chinese juniper over time. Chinese juniper was chosen because of the wide range of crown forms available within this species.

\section{Materials and Methods}

The study was conducted on an Arrendondo fine sand (loamy, siliceous, hyperthermic Grossarenic Paleudults) with a $\mathrm{pH}$ of 6.1. Eleven-1iter, container-grown 'Pfitzeriana', 'Hetzii', 'Sylvestris', and 'Torulosa' Chinese junipers, representing spreading, upright spreading, fastigiate, and columnar forms, respectively, were planted 19 Sept. 1986. Plants were placed on 2.5-m centers in four blocks (two replications of each cultivar to a block). A 10-cm-thick layer of coarse hardwood-chip mulch was spread on a $1.8-\mathrm{m}^{2}$ area around each plant to simulate a landscape planting. A 30-cm-wide weed-free zone was maintained with $N$-(phosphonomethyl)glycine (glyphosate) around the edge of the mulch. Ammonium nitrate at $0.97 \mathrm{~kg} \mathrm{~N} / 100 \mathrm{~m}^{2}$ per application was uniformly broadcast over the surface of the mulch in October, March, and July of each year. Overhead irrigation was provided to ensure that the plot received a minimum of 2.5 $\mathrm{cm}$ of water weekly during the growing season.

In Aug. 1987, the trunk was severed at ground line on four plants (one from each block) of each cultivar. The entire root system on each plant was excavated with hand shovels and their location mapped to scale on graph paper. The remaining plants were on $5-\mathrm{m}$ centers, and the mulched area around each was increased to $6.0 \mathrm{~m}^{2}$. In mid-Summer 1988, two plants of each cultivar were harvested and roots were excavated and mapped. Following excavation, the mulched area on remaining trees was increased to $13.6 \mathrm{~m}^{2}$. Three years after planting (mid-Summer 1989), two plants of each cultivar were harvested and roots 
excavated and mapped. The diameter of the root system was measured through the trunk to the tip of the roots. Mean root spread was calculated by averaging the north-south, northeastsouthwest, east-west, and southeast-northwest root-spread diameters. The largest root-spread diameter was recorded as maximum root spread. A line was constructed around the periphery of the root system and the area within this roughly circular shape was recorded as root area.

All roots were collected each year from the top $45 \mathrm{~cm}$ of soil from several zones around each plant: a) within the branch dripline; b) outside the dripline; c) within a 0.9 -m-diameter circle, centered at the trunk; and d) within 0.45-m-wide rings outside of this circle. In 1988 and 1989, roots beneath the dripline located within the original container rootball were separated from those outside the rootball. After washing soil from roots, lengths of all roots in each zone were estimated with Newman's line-intersection method for individual plants (Newman, 1966). Root length density (RLD) was calculated as meter of root length per cubic meter of soil. Roots were dried at 70C to constant weight. Since root weight was correlated with root length in 1987 and 1988, only root weight was measured on plants harvested in 1989 .

The edge of the branches was projected onto the ground with a plumb bob and recorded. Branch-spread diameter was measured in a straight line from branch tip to branch tip through the trunk. Mean branch-spread diameter was calculated from the largest branch-spread diameter and three other equally spaced diameters. The ground area within the branch dripline was recorded as crown area. Plant heights were measured according to American Assn. of Nurserymen (AAN) standards (Amer. Assn. Nurserymen, 1986). Cross-sectional area of the trunk(s) was calculated from the diameter measured at ground line at planting and at harvest in each year. Areas were added together if the plant had multiple trunks. Crown area and root area were measured with a Delta T area meter (Decagon Instruments, Pullman, Wash.). Foliage, branches, and trunk were dried together at 70C to constant weight. Shrubs were planted in a randomized complete block design, and data were analyzed with analysis of variance. The restriction placed on the multiple regression equations was significant $\mathrm{F}$ values at $P<0.05$.

\section{Results}

Length of roots outside of the original container rootball was correlated with dry weight 1 year $(r=0.90)$ and 2 years $(r=$ 0.89) after planting. Root length 3 years after planting (1989) was calculated from the least squares linear equation [root length $(\mathrm{m})=142.86 \times$ root dry weight $(\mathrm{g}), R^{2}=90 \%$ ] developed from combined length and weight data from both years.

There was no significant $(P<0.05)$ difference among cultivars in mean root spread or root area (Fig. $1 \mathrm{~A}$ and B) or maximum root spread (data not presented) 1 or 2 years after planting. However, 3 years after planting, roots on 'Hetzii', 'Pfitzeriana', and 'Sylvestris' were spread over a greater $(P<$ $0.05)$ area $\left(>10 \mathrm{~m}^{2}\right)$ than on 'Torulosa'. The rate of increase in mean and maximum root-spread diameter averaged 1.2 and $1.6 \mathrm{~m} \cdot$ year $^{-1}$ respectively, among cultivars for the first 3 years after planting. Mean root-spread diameter and root area increased quadratically during the first 3 years after planting.

Length of roots in each root-spread diameter interval increased with time (Fig. 2 A-D). There were no significant differences in root length among cultivars 1 year after planting $(P<0.01)$. At the end of the 2 nd year, 'Sylvestris' and 'Pfitzeriana' had more root length than 'Torulosa' in the 0.9 to $<1.8$ -
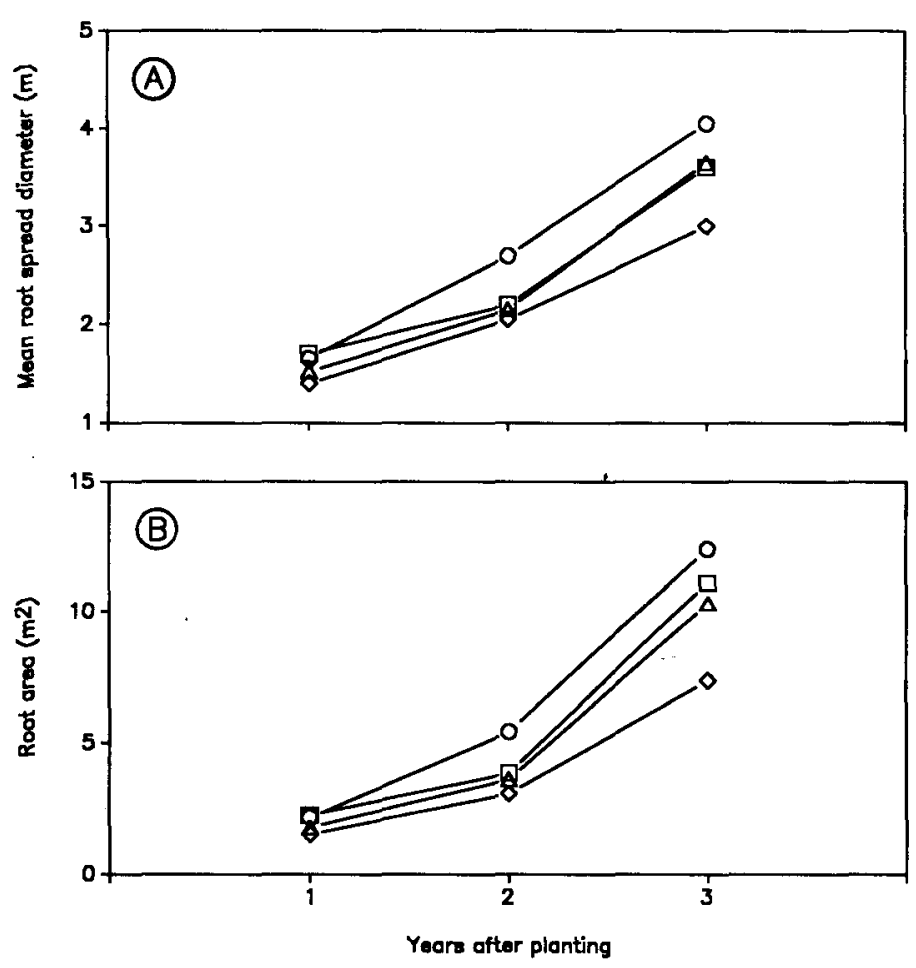

Fig. 1. Mean root-spread diameter (A) and root area (B) for 'Hetzii' $(O)$, 'Pfitzeriana' $(\square)$, 'Sylvestris' $(\triangle)$, and 'Torulosa' $(\diamond)$ Chinese juniper 1,2 , and 3 years after planting from containers. Root-spread diameter (in meters) (all cultivars combined) $=1.46-0.18 \mathrm{Y}+$ $0.29 \mathrm{Y}^{2}, R^{2}=85 \%$; root area (in square meters) (all cultivars combined) $=4.15-4.35 \mathrm{Y}+2.13 \mathrm{Y}^{2}, R^{2}=88 \%$; $\mathrm{Y}=$ years after planting. Data points 1 year after planting were calculated from four plants. Data points 2 and 3 years after planting were calculated from two plants.

$\mathrm{m}$ root-spread diameter interval. At the end of the 3rd year, 'Sylvestris' had more root length than 'Torulosa' in the <0.9$\mathrm{m}$ and 0.9 to $<1.8-\mathrm{m}$ intervals $(P<0.05)$. Root length of 'Torulosa' in the 1.8 to $<2.7-\mathrm{m}$ interval was less than that for the other three cultivars. There were no other significant differences among cultivars (LSD, $P<0.05$ ). Three years after planting, RLD (mean of all cultivars) was $1600 \mathrm{~m} \cdot \mathrm{m}^{-3}$ in the $<0.9-\mathrm{m}$ interval, $717 \mathrm{~m} \cdot \mathrm{m}^{-3}$ in the 0.9 to $<1.8-\mathrm{m}$ interval, and $192 \mathrm{~m} \cdot \mathrm{m}^{-3}$ in the 1.8 to $<2.7-\mathrm{m}$ interval.

Two years after planting, 'Sylvestris' had more total root length than 'Torulosa' (Table 1), and 3 years after planting, 'Sylvestris' had greater total root length $(7850 \mathrm{~m})$ than all other cultivars. Root length within the original container rootball averaged across all cultivars represented $22.2 \%$ and $13.6 \%$ of total root length in 1988 and 1989, respectively (Table 1). The percentage of total root length located beneath the dripline was $55 \%$ and $48 \%$ for 'Torulosa', $78 \%$ and $78 \%$ for 'Sylvestris', $53 \%$ and $71 \%$ for 'Pfitzeriana', and $82 \%$ and $82 \%$ for 'Hetzii' in 1988 and 1989, respectively.

Plant height and branch spread increased linearly with time, whereas trunk cross-sectional area and crown area increased quadratically $(P<0.05)$ (data not shown). When analyzed as one data set, including all cultivars, trunk area was correlated with root spread and root area [root spread $(\mathrm{m})=1.255+$ $0.066 \times$ trunk cross-sectional area $\left(\mathrm{cm}^{2}\right), R^{2}=79 \%$; root area $\left(\mathrm{m}^{2}\right)=0.456+0.272 \times$ trunk cross-sectional area $\left(\mathrm{cm}^{2}\right), R^{2}$ $=79 \%$ ]. The quadratic relationships of root area with crown area were similar for 'Sylvestris', 'Hetzii', and 'Pfitzeriana' 
(Fig 3A). Root-spread diameter increased faster than branchspread diameter (Fig. 3B). The relationships were linear for 'Torulosa'.

Shoot and root dry weights at planting varied, but shoot : root ratio (mean $=3.7$ ) was similar for all cultivars (Table 2 ). In the first 2 years after planting, shoot weight increased by a factor of 6.4 and root weight by a factor of 4.8 , leading to an

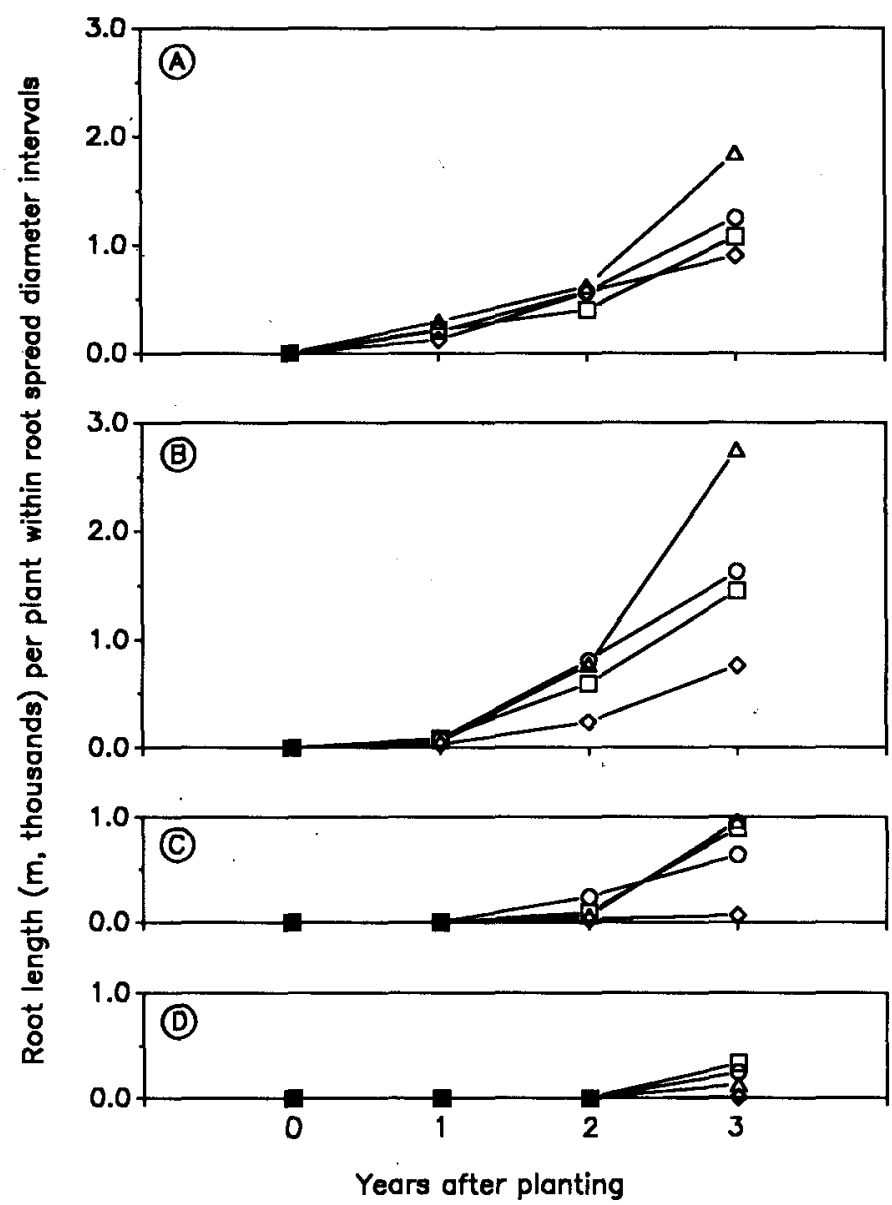

Fig. 2. Length of roots per plant outside of the original container rootball within $0.9 \mathrm{~m}$ of the trunk $(\mathrm{A})$, between 0.9 and $1.8 \mathrm{~m}(\mathrm{~B})$, between 1.8 and $2.7 \mathrm{~m}(\mathrm{C})$, and $>2.7 \mathrm{~m}$ from the trunk (D) for 'Hetzii' $(0)$, 'Pfitzeriana' $(\square)$, 'Sylvestris' $(\Delta)$, and 'Torulosa' $(\diamond)$ Chinese juniper at planting and 1,2 , and 3 years after planting from containers. Data points 0 and 1 year after planting were calculated from four plants. Data points 2 and 3 years after planting were calculated from two plants. increase in shoot : root ratio (5.0) averaged over four cultivars. However, in the third growing season, rate of shoot biomass accumulation slowed, whereas root biomass increased by $150 \%$, corresponding to a lower shoot : root ratio $($ mean $=3.0)$.

\section{Discussion}

The diameter of the root system expanded quadratically with time. RLD increased during the first 3 years after planting but decreased with distance from the trunk. Under the uniform conditions of this study, root spread of plants increased quickly, then RLD increased beginning with the areas closest to the trunk. The portion of the primary lateral roots farthest from the trunk gave rise to only a few secondary branch roots. The many secondary and finer branch roots closer to the trunk were responsible for the increase in RLD in that area. Further study is needed to determine when maximum root density is reached. Plantation-grown Japanese cedar [ Cyptomeria japonica L.f. (D. Don)] (Karizumi, 1968) and red pine (Fayle, 1974) required 15 to 20 years to reach maximum root density.

Numerous primary lateral roots grew straight, in a radiating pattern, from the trunks of plants used in this study, which is typical for conifers (Reynolds, 1986), but not for deciduous trees (Stout, 1956). Second-order lateral roots branching from the primary lateral roots grew perpendicular to and were much smaller in diameter than the primary lateral roots, which is typical for many plants (Sutton and Tinus, 1983). Occasionally, a branch root grew to the same or similar size as the main lateral. The distance between lateral roots gradually increased with increasing distance from the trunk, much like spokes on a wheel. This pattern may have accounted for the reduction in RLD at increasing distances from the trunk. Other researchers have reported a low RLD toward the edge of the root system during the first 2 years after planting (Fayle, 1974). However, by 3 years, root systems of plantation-grown radiata pine [ Pinus radiata (D. Don)] were overlapping and RLD was independent of distance from the trunk (Nambiar, 1983). Root systems did not overlap in the current study. Increased RLD close to the trunk may be due to lower temperature (although it was not measured in the current study) in soil shaded by the foliage, as found in chaparral shrubs (Kummerow et al., 1977). RLD beneath the dripline may increase due to higher nitrogen concentration in this area from accumulating dead foliage (Nobel, 1989). However, as Coile (1937) showed and the current study supports, root length per unit area of soil increases with time. Therefore, increased RLD closer to the trunk may simply result from earlier colonization in this area soon after planting

Length rapidly increases along a root that grows into soil

Table 1. Root length (in meters) of four cultivars of Chinese juniper 1, 2, and 3 years $(1987,1988$, 1989 , respectively) after planting. ${ }^{2}$

\begin{tabular}{|c|c|c|c|c|c|c|c|c|}
\hline \multirow[b]{3}{*}{ Cultivar } & \multirow{2}{*}{\multicolumn{2}{|c|}{ Total root length }} & \multirow{2}{*}{\multicolumn{3}{|c|}{$\begin{array}{c}\text { Outside container root ball } \\
\text { Years after planting }\end{array}$}} & \multirow{2}{*}{\multicolumn{3}{|c|}{$\begin{array}{c}\text { Outside container root ball } \\
\text { beneath branch dripline }\end{array}$}} \\
\hline & & & & & & & & \\
\hline & 2 & $3^{y}$ & 1 & 2 & $3^{y}$ & 1 & 2 & $3^{y}$ \\
\hline Torulosa & $1135 \mathrm{a}^{\mathrm{x}}$ & $2661 \mathrm{a}$ & 156 & 839 & 2057 a & 62 & $333 \mathrm{a}$ & $673 \mathrm{a}$ \\
\hline ylv & $35 \mathrm{~b}$ & $7850 \mathrm{~b}$ & 35 & 153 & $6889 \mathrm{~b}$ & 25 & 1102 & $5221 \mathrm{~b}$ \\
\hline Pfitze & $1583 \mathrm{ab}$ & $4722 \mathrm{a}$ & 301 & 125 & 4320 & 23 & 504 & $2958 \mathrm{ab}$ \\
\hline Hetzii & $1681 \mathrm{ab}$ & 4882 a & $283 \mathrm{~b}$ & $1323 \mathrm{a}$ & $4351 \mathrm{ab}$ & $210 \mathrm{~b}$ & $1017 \mathrm{ab}$ & $3486 \mathrm{~b}$ \\
\hline
\end{tabular}

${ }^{\mathrm{Z}}$ Plants were installed Sept. 1986 and excavated in summer of indicated year.

${ }^{y}$ Root lengths for $1989=142.86 \times$ root dry weight. This equation calculated from root length and dry weight data from 1987 and 1988.

${ }^{\mathrm{x}}$ Mean separation within columns by Duncan's multiple range test, $P=0.05$. Means for 1987 are averaged from four plants. Means for 1988 and 1989 are averaged from two plants. 
favorable for growth (Eissenstat and Caldwell, 1988). This increase may help the plant grow rapidly and outcompete surrounding plants due to increased availability of water and nutrients. A plant that expands the root system rapidly and increases density later may have a competitive advantage over one that develops a uniformly dense, but slowly expanding root system, such as green ash (Gilman, 1988a). This strategy may benefit plants growing in poor soil, since roots could quickly reach pockets of fertile or moist soil remote from the trunk. However, there may be no advantage to this strategy in fertile soil or where there is no competition from surrounding plants.

Although branch spread increased linearly, the relationship
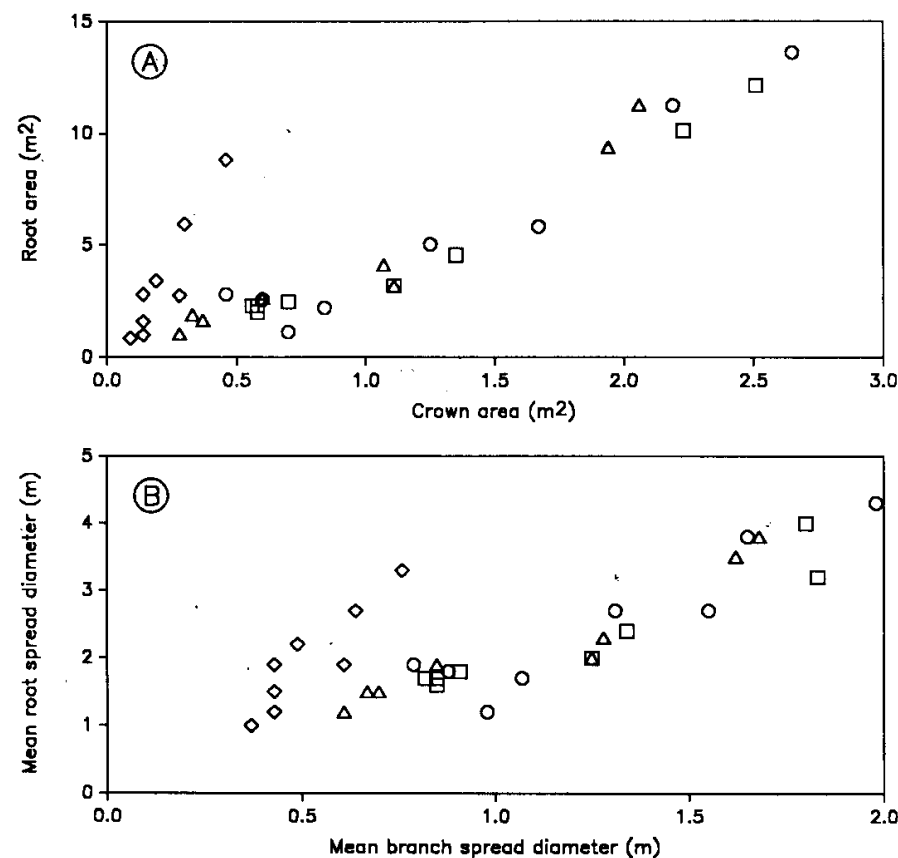

Fig. 3. Relationship between root area and crown area (A) and root spread and branch spread (B) for 'Hetzii' (O), 'Pfitzeriana' ( $\square$ ), 'Sylvestris' $(\triangle)$, and 'Torulosa' $(\diamond)$ Chinese juniper. Root area (in square meters $)=1.16+0.70 \mathrm{CA}+1.59 \mathrm{CA}^{2}, \mathrm{CA}=$ crown area (in square meters), $R^{2}=96 \%$; root spread (in meters) $=1.48-$ $0.81 \mathrm{BS}+1.15 \mathrm{BS}^{2}, \mathrm{BS}=$ branch spread (in meters), $R^{2}=90 \%$. Each data point is an individual plant. between soil area colonized by the roots (root area) and that covered by the branches (crown area) was quadratic. This pattern is due to a more rapid rate of increase in root spread than branch spread. Consequently, the mean root spread : branch spread ratio increased from 1.95 one year after planting to 2.75 three years after planting. In addition, the ratio mean root area : branch area increased to 5.5 three years after planting. Since both ratios increased with time, there was no static balance between shoots and roots, and this may indicate that plants were not yet established. Kramer and Kozlowski (1979) suggest that the shoots of established plants are in balance with the roots. A changing shoot : root dry weight ratio with time also supports lack of establishment 3 years after planting. This ratio was 3.7 at planting, 5.0 two years later, and 3.0 at the conclusion of the study. Root biomass accumulated faster between years 2 and 3 than it did in the first 2 years after planting. A similar lag in root growth following planting was reported for red pine, in which roots grew fastest between 4 and 9 years after planting (Fayle, 1974). Trees of various species between 3 and 40 years old have a shoot : root dry weight ratio (2.9-4:1) (Cote and Camire, 1987; Strong and LaRoi, 1983) that, except for seasonal fluctuations (Vogt et al., 1980), remains relatively constant (Kramer and Kozlowski, 1979). Shoot : root ratio for established trees cited above is remarkably similar to that of the container-grown juniper at planting (3.7) in the current study.

Roots on established trees extend to about three times the edge of the branches (Gilman, 1988a; Rogers, 1933; Watson and Himelick, 1982). This difference may indicate that junipers planted from containers in the current study were nearing establishment 3 years after planting, since the mean (among cultivars) ratio of root spread : branch spread was 2.75. Trees transplanted from field nurseries required $\approx 1$ year $/ 2.5 \mathrm{~cm}$ of trunk caliper to regenerate the root system to the original size before transplanting (Gilman, 1990b; Watson, 1985). The length of time required to establish a new planting is important since established plants may be more tolerant of drought than those that are not.

Root spread : branch spread ratio varies considerably among genera (Gilman, 1988a; Kummerow et al., 1977) and is influenced by competition from other plants (Fayle, 1974). The tips of the longest roots on poplar, honey locust (Gilman, 1988b), and southern magnolia (Gilman, 1988a) extended from the trunk

Table 2. Shoot and root dry weight of four cultivars of Chinese juniper at planting and 2 and 3 years after planting. ${ }^{2}$

\begin{tabular}{|c|c|c|c|c|c|c|c|}
\hline \multirow[b]{2}{*}{ Cultivar } & \multirow[b]{2}{*}{ Organ } & \multicolumn{2}{|c|}{ At planting (Sept. 1986) } & \multicolumn{2}{|c|}{ Second year } & \multicolumn{2}{|c|}{ Third year } \\
\hline & & $\begin{array}{c}\text { Dry wt } \\
\text { (g) }\end{array}$ & $\begin{array}{c}\text { Shoot : root } \\
\text { ratio }\end{array}$ & $\begin{array}{c}\text { Dry wt } \\
(\mathrm{g})\end{array}$ & $\begin{array}{c}\text { Shoot : root } \\
\text { ratio }\end{array}$ & $\begin{array}{c}\text { Dry wt } \\
(\mathrm{g})\end{array}$ & $\begin{array}{c}\text { Shoot : root } \\
\text { ratio }\end{array}$ \\
\hline Torulosa & Shoot & $566 b^{y}$ & & $2606 \mathrm{a}$ & & $3125 \mathrm{a}$ & \\
\hline & Root & $140 \mathrm{~b}$ & $4.0: 1$ & $467 \mathrm{a}$ & $5.6: 1$ & & $2.4: 1$ \\
\hline Sylvestris & $\begin{array}{l}\text { Shoot } \\
\text { Root }\end{array}$ & $\begin{array}{l}458 \mathrm{~b} \\
133 \mathrm{~b}\end{array}$ & $3.4: 1$ & $\begin{array}{c}3656 \mathrm{a} \\
680 \mathrm{a}\end{array}$ & $5.5: 1$ & $\begin{array}{l}8264 \mathrm{~b} \\
2420 \mathrm{a}\end{array}$ & $3.4: 1$ \\
\hline Pfitzeriana & Shoot & $247 \mathrm{a}$ & 4.1:1 & $2517 \mathrm{a}$ & $3.6: 1$ & 2492 a & $2.2: 1$ \\
\hline Hetzii & $\begin{array}{l}\text { Root } \\
\text { Shoot }\end{array}$ & $\begin{array}{r}60 a \\
602 b\end{array}$ & & $\begin{array}{r}707 \mathrm{a} \\
3211 \mathrm{a}\end{array}$ & & $\begin{array}{l}1133 \mathrm{a} \\
4802 \mathrm{a}\end{array}$ & \\
\hline & Root & $179 \mathrm{c}$ & & $580 \mathrm{a}$ & . & $1207 \mathrm{a}$ & \\
\hline
\end{tabular}

${ }^{\mathrm{z}}$ All tissue above ground line was considered shoot. All tissue below ground was considered root. ${ }^{y}$ Separation of shoot and root means by Duncan's multiple range test, $P=0.05$. Means for 1986 are averaged from four plants. Means for 1988 and 1989 are averaged from two plants. 
to three or more times the edge of the branches, whereas the edge of the root system was less than twice the branch spread on green ash growing on the same site. The difference in root spread : branch spread ratio among cultivars in the current study could be largely accounted for by differences in crown shape, since root spread was similar among cultivars (except 'Torulosa' had less spread than 'Hetzii'). Together, these studies indicate that differences in root spread : branch spread ratio among woody plants may be largely attributable to the shape of the crown, not different root growth rates. Increase in mean root-spread diameter for juniper in the current study $\left(1.2 \mathrm{~m} \cdot \mathrm{year}^{-1}\right)$ was similar to rates on trees from a variety of genera growing in the same area of the country $\left(1.4 \mathrm{~m} \cdot \mathrm{year}^{-1}\right)$ in a similar soil type (Gilman, 1988a).

Gilman (1988a) and Stout (1956) showed that root spread on established small and large trees, respectively, can be predicted from trunk cross-sectional area or diameter, or from branch spread. Trunk cross-sectional area, crown area, and branch spread on juniper shrubs in the current study were also correlated with root spread and root area. This result shows that during the 3 years following planting, trunk and crown growth are related to root growth in a predictable way.

In conclusion, shoot weight on container-grown juniper increased faster than root weight in the first 2 years after planting into the landscape. Root weight increased fastest during the 3rd year after planting. Roots covered an area 5.5 times that covered by the branches, and root spread was almost three times branch spread 3 years after planting. Shoots and roots on establishing plants grow in a predictable manner. Plants maybe considered established when the ratios of shoot : root dry weight, branch spread : root spread, and branch crown area : root area are static within a narrow range of values. Chinese junipers planted from 11-liter containers require at least 3 years to become established in the landscape.

\section{Literature Cited}

American Association of Nurserymen. 1986. American standard for nursery stock. Amer. Assn. Nurserymen, Washington, D.C.

Blessing, S.C. and M.N. Dana. 1988. Post-transplant root system expansion in Juniperus chinensis L. as influenced by production system, mechanical root disruption, and soil type. J. Environ. Hort. 5:155-158.

Bushey, D.J. 1937. Root extension of shade trees. Proc. Intl. Shade Tree Conf. 13:22-30.

Coile, T.S. 1937. Distribution of forest tree roots in North Carolina piedmont soils. J. For. 36:247-257.

Cote, B. and C. Camire. 1987. Tree growth and nutrient cycling of hybrid poplar and black alder. Can. J. Forest Res. 17:516-523.

Eissenstat, D.M. and M.M. Caldwell. 1988. Seasonal timing of root growth in favorable microsites. Ecology 69:870-873.

Fayle, D.C.F. 1974. Extension and longitudinal growth during the development of red pine root systems. Can. J. Forest Res. 5:109121.

Gilman, E.F. 1988a. Predicting root spread from trunk diameter and branch spread. J. Arboriculture 14:85-89.

Gilman, E.F. 1988b. Tree root spread in relation to branch dripline and harvestable rootball. HortScience 23:351-353.

Gilman, E.F. 1989. Plant form in relation to root spread. J. Environ. Hort. 7:88-90.
Gilman, E.F. 1990a. Tree root growth and development. II. Response to culture, management and planting. J. Environ. Hort. 8:220-227.

Gilman, E.F. 1990b. Tree root growth and development. I. Form, depth, spread and periodicity. J. Environ, Hort. 8:215-220.

Hodgkins, E.J. and N.G. Nichols. 1977. Extent of main lateral roots in natural longleaf pine as related to position and age of the tree. Forest Sci. 23:161-166.

Karizumi, N. 1968. Estimation of root biomass in forests by the soil block sampling, p. 78-86. In: M.S. Ghilarov, V.A. Kovda, L.N. Novichkova-Ivanova, L.E. Rodin, and V.M. Sveshnikova (eds.). Methods of productivity studies in root systems and rhizosphere organisms. Publication House Nauka, Leningrad, Soviet Union.

Kramer, P.J. and T.T. Kozlowski. 1979. Physiology of woody plants. Academic, New York.

Kummerow, J., D. Krause, and W. Jew. 1977. Root systems of chaparral shrubs. Oecologia 29:163-177.

Nambiar, E.K.S. 1983. Root development and configuration in intensively managed radiata pine plantations. Plant \& Soil 71:37-47.

Newman, E.I. 1966. A method of estimating the total length of roots in a sample. J. Applied Ecol. 3:129-145.

Nobel, P.S. 1989. Temperature, water availability and nutrient levels at various soil depths - Consequences for shallow-rooted desert succulents, including nurse plant effects. Amer. J. Bet. 76:1486-1492.

Preisig, C. L., W.C. Carlson, and L.C. Promnitz. 1979. Comparative root morphologies of seeded-in-place, bareroot and containerized Douglas-fir seedlings after outplanting. Can. J. Forest Res. 9:399405.

Reynolds, E.R.C. 1986. Development of the root crown in some conifers. Plant \& Soil 98:397-405.

Rogers, W.S. 1933. Root studies III. Pears, gooseberry and black currant root systems under different soil fertility conditions with some observation on root stock and scion effect in pears. J. Pomol. Hort. Sci, 11:1-18.

Rogers, W.S. and M.C. Vyvyan. 1934. Root studies V. Root stock and soil effect on apple root systems. J. Pomol. Hort. Sci. 12:110150 .

Stout, B.B. 1956. Studies of the root systems of deciduous trees. Black Rock Forest Bul. 15. Harvard Univ., Cornwall-on-the-Hudson, N.Y.

Strong, W.L. and G.H. LaRoi. 1983. Root-system morphology of common boreal forest trees in Alberta, Canada. Can. J. Forest Res. 13:1164-1173.

Sutton, R.F. and R.W. Tinus. 1983. Root and root system terminology. Forest Sci. 29.

Van Eerden, E. and T.E. Kinghorn (eds.). 1978. Proc. Root Form Planted Trees Symp. British Columbia Ministry Forests/Can. Forest Serv. Joint Rpt. 8. Providence British Columbia, Ministry Forests, Victoria, B. C., Canada.

Vogt, K. A., R.L. Edmonds, and C.C. Grier. 1980. Seasonal changes in biomass and vertical distribution of mycorrhizal and fibrous-textured conifer fine roots in 23- and 180-year-old subalpine Abies amabilis stands. Can. J. Forest Res. 11:223-229.

Watson, G.W. 1985. Tree size affects root regeneration and top growth after transplanting. J. Arboriculture 11:37-40.

Watson, G. W. and E.B. Himelick. 1982. Root distribution of nursery trees and its relationship to transplanting success. J. Arboriculture $8: 225-229$.

Watson, G.W. and T.D. Syndor. 1987. The effect of root pruning on the root system of nursery trees. J. Arboriculture 13:126-130.

Wilson, W.F. 1964. Structure and growth of woody roots of Acer rubrum L. Harvard Forest Paper 11. Harvard Univ., Harvard Forest, Petersham, Mass. 